\title{
Factors Influencing Consumer's Purchase Intention on Social Networking Sites: Evidence from Bangalore
}

Sayyed Arbaina* and A S Suresh ${ }^{\dagger}$

\begin{abstract}
Most online shoppers indicate that they visit e-retail websites on a social networking site. Previous research shows that visiting websites affect the consumer's purchase intentions. This study identified various factors that affect consumer behaviour while shopping on social media. It further studied the services offered by social media and several factors that influence the consumer's purchasing experience in social networking sites. Analysing 105 responses, the study revealed that factors such as price, services offered, advertising attitude, and shopping attitude have a significant impact on consumer behaviour.
\end{abstract}

Keywords: Social Media, Consumer Purchase Intention, Advertisement Attitude, Shopping Attitude, E-retail Websites

\section{Introduction}

Social media offers new opportunities for the companies and the consumers to interact with each other on a real-time basis. Therefore, the onus is on the companies to envisage a strategy so that they can make their presence felt on social networking sites. Though some companies initiated a process to rething strategies of

"Institute of Management, CHRIST (Deemed to be University), Bengaluru, India; sayyed.arbaina@mba.christuniversity.in

† Institute of Management, CHRIST (Deemed to be University), Bengaluru, India; suresh.a@christuniversity.in 
advertising, it is essential that their sites are easily accessible to customers in order to become successful. There is a plethora of information on social media sites. If the service provided is not according to a consistent standard, the sites and the companies soon lose their credibility. A formal social media presence with a designated workforce not only helps in building customer relationships but also helps in introducing the brand to potential consumers effectively.

Social media has gained acceptance from the vast majority of people worldwide. It has become a part of our lives and is now increasingly being used for information transaction. Customers consider it as a platform not only for social encounters but also for shopping, and exchanging information. Today, businesses are trying to capitalise on this. With specific reference to shopping online, it is considered convenient by many customers, especially for those who find a wide range of products under one platform helpful due to their frenzied schedules.

\section{Review of Literature}

Michael Pütter (2017) stated that the use of social media has increased drastically. This has led to social media being considered as a powerful tool for consumer engagement. Companies are continuously looking for new methods for connecting to consumers and shaping consumer behaviour, including building brand loyalty and influence the customers' purchase intentions.

He argues that the changing technological era has led to increased activity on social networking platforms like Facebook, YouTube, and Twitter. They have created mechanisms through which consumers can develop familiarity with brand-specific content. Researchers have opined that companies with better strategic approaches are likely to be more successful in handling and fulfilling such multiple demands. The factors that influence brand perception and purchase intention include the mechanisms that drive consumer perspectives, including customer reviews. An emerging strategic focus is on the use of user-generated content, that is, content that is created by consumers in response to specific brands or brand requests and which often influences the 
perceptions of other consumers. This requires maintenance and companies should be prepared to designate a marketing service to the management of online customer relationships.

Parson (2013) argued that Facebook is a platform for socialising and is used quite frequently to acquire information. Lately, it has also become a platform for shopping. Individuals shop but they also consider the comments on the product pages before purchasing. Today, Facebook caters to over 6 million customers to share their personal information. The study revealed that social media is a useful platform to consider for receiving feedback about a specific product or a certain brand. It further stated that $51 \%$ of users buy various products through social media, specifically referring to Facebook.

Kronrod, Ann, and Danziger, Shai (2013) found that unlike earlier times when 'word of mouth' (WOM) publicity could influence the purchase of a product, today, E-WOM happens through sharing information of a particular product on social media which customers review before purchasing online. Online sites have a separate section for reviews whereas social media have comment sections where people across the globe share their point of view or experience of the product.

Shen and Bissell (2013) said that social networking sites like Facebook, Twitter, Instagram and so on are platforms for introducing a new brand, product/s, and exchange information amongst users. About $93 \%$ of businesses use some form of social networking for marketing and branding. There are more than 200 million active online users in the United States who spend more than 29 hours on online browsing, product assessment, and networking.

Dholakia (2013) revealed that shopping online is considered convenient because individuals find a wide range of products under one platform and the sites are usually user-friendly. This is a time saving effictent alternative. Customers can shop online $24 * 7$ from anywhere with internet access. Similarly, social media also operates $24 / 7$, offering the same services along with a wide range of products and brands to choose from. 
Krieger (2012) opined that Instagram is witnessing a huge growth as a social media platform. Over 16 million photos are usually shared among the users on Instagram. One can easily recommend, share, or send direct messages about the product or service to the user. People consider the information provided in the comments section as reliable. Moreover, users of Instagram are highly influenced if the brand provides cash on delivery (COD).

Darden and Reynolds (2011) noted that sharing information after the purchase is integral for the consumer. By sharing information, one can refer the product to other users. In this process, the brand gets recognition. Sharing information on the social media platform is considered as the electronic word of mouth (E-WOM) for those who want to buy a product. Therefore, social media is considered a business tool for various brands as well as a platform for product related information transaction.

Han and Han (2011) found that the internet provides customised advertisements depending upon their past data or activity. Through profiling performed by social media websites, customised advertisements appear to users based on their specific interests and likings. This enhances user intention for searching as well as purchasing products. Bennett, Owers, and Tucker (2010) opine that the emergence of social media has helped an individual to connect, have provided a platform for entrepreneurship ventures besides offering information of all kinds.

Miller and Lammas (2010) stated that Twitter has reached 8,00,000 followers keen on providing services about products. It is considered a platform for socialising and sharing one's views or information that could reach a wide audience very easily. The written blogs have increased from $54 \%$ to $77 \%$ within two years and watching videos of various product advertisements have changed from 32\% in 2006 to $83 \%$ in 2010 .

Mitra, Reiss, and Capella (2009) stated that customers use the internet to get information and access reviews about the product before shopping. The social media integrates information from a 
number of sources thus providing users with the necessary information about a product.

Boyd and Ellison (2007) said that the rise of social networking (SN) has been significant. Its influence spans beyond global boundaries, transcending even social, and cultural boundaries. The development of social networking sites, and the extensive use of such sites for social and business purposes have created an emergent global phenomenon. Li, Bernoff, Pflaum, and Glass (2007) opined that online WOM allow consumers to gather and obtain information from different groups of people. 50 percent of adult users of online social networks share and talk about the products they like and consider the reviews reliable. Extending the observation, Kim and Srivastava (2007) stated that the information search' is a crucial step for consumers that reduces the risk and leads them to a better purchase decision. Many consumers check other recommendations (WOM) before making any purchasing decision especially when it comes to buying new products.

McKnight and Chervany (2002) stated that in marketing, trust is examined from the point of view of relational marketing. Trust alludes to customer's trust in social networking sites. Trust building is an important factor for companies or brands because the lack of it could lead to the closure of the company. Trust can be built in various ways. If the brand is new, providing few testimonies of various customers, providing freebies, offering a convenient mode of payment (Cash on Delivery) and so on is shown to be helpful.

\section{Locating the Relevance of the Study}

Empirical studies in the area of online shopping have predominantly focussed on the idea of social media and ecommerce. There are no studies integrating consumer behaviour aspects and their effects on the consumer's brand choice, purchase quantity, and category frequency when using different types of social networking sites. Multiple variables have been posited. However, not all factors affecting consumer behaviour have been considered in a systematic manner across the studies reviewed. 
This study is an attempt to evolve a comprehensive framework for social media drivers of shopping strategies.

\subsection{Statement of the Problem}

Increasingly, social media is becoming a powerful platform for consumer engagement. Most online shoppers indicate that they visit e-retail websites on a social networking site. Consumer's purchase intention is affected by the content and services provided in the website of individual companies. It is, therefore, crucial to garner insights on factors that influence consumer behaviour through social media, primarily by analysing data collected from respondents located in Bangalore. The study was undertaken to examine the purchase behaviour of customers and delineate whether shopping through social networking sites has any impact on the purchase behaviour of the customers.

\subsection{Conceptual Framework}

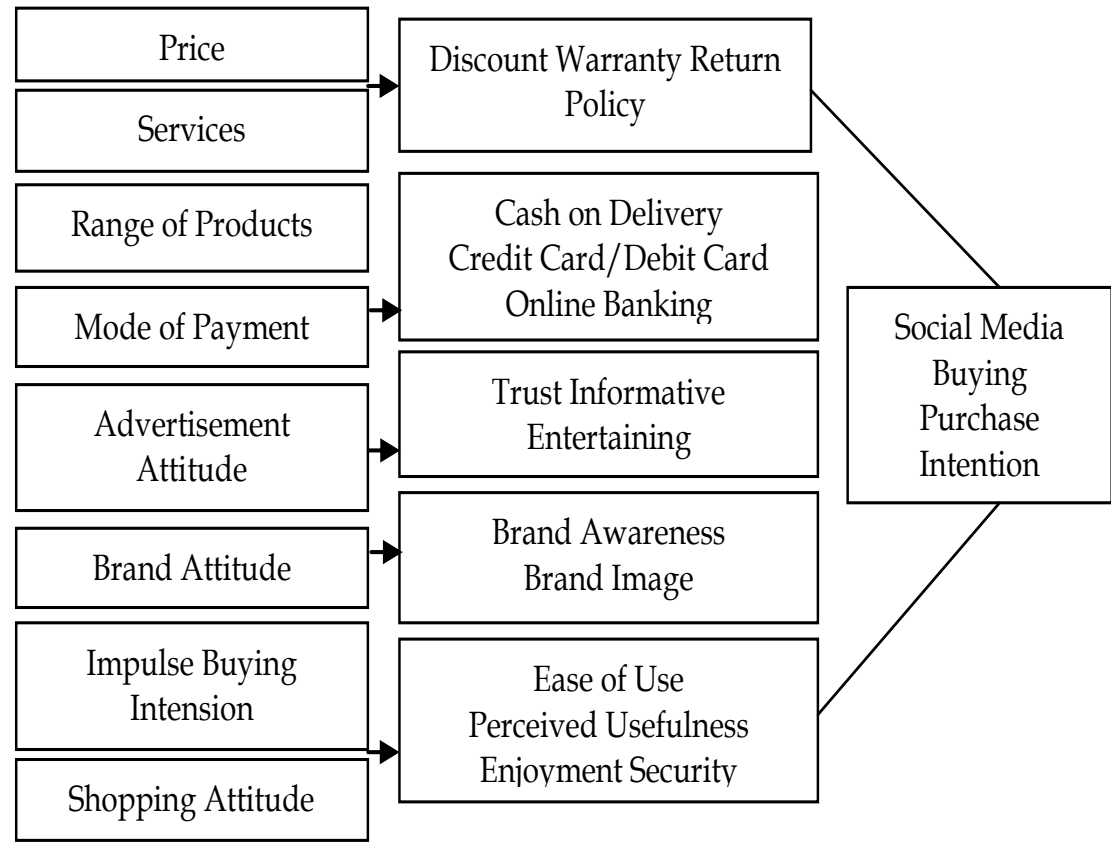




\subsection{Objectives}

1. To ascertain the services offered by various social networking sites (price, range of products, discounts, warranty, return policy, and mode of payment)

2. To identify the factors and their interrelations that affect consumers whilst shopping through social networking sites (price, range of products, advertisement attitude, brand attitude, impulse buying intention, and shopping attitude)

\subsection{Hypotheses}

H1: There is a positive and significant relationship between services offered (price, range of products, discounts, warranty, return policy, and mode of payment) and consumer purchase intention on social networking sites.

\section{Hypothesis-2}

H2: There is a positive and significant relationship between advertisement, brand, shopping attitude, impulsive buying intention, and consumer's purchase intention on social networking sites.

\subsection{Research Design}

The tools employed for generating the responses in the study were based on a structured questionnaire survey. The questionnaire included the rationale of the study as well.

\subsubsection{Population}

The study was conducted mainly in Bangalore. Simple random sampling was used as a statistical data collection method to obtain data. The number of samples collected was 105 .

\subsubsection{Instrument}

The questionnaire used for this study included the following types of scales and questions: Likert Scale [Strongly Agree/Agree/Neutral/Disagree/Strongly Disagree] 
For analysis of the data, SPSS 21 and advanced Excel applications were used. Descriptive Statistics and Factor Analysis were used to further validate the hypotheses.

\section{Data Analysis and Interpretation}

\subsection{KMO and Bartlett's Test}

The KMO measures the sampling adequacy (which determines if the responses given with the sample are adequate or not) which should be closer to 0.5 for a satisfactory $\mathrm{F}$ actor analysis to proceed. Kaiser (1974) recommends 0.5 value for KMO as minimum (barely accepted); values greater than 0.5 as acceptable, and values between 0.5 and 0.7 as mediocre. The values between 0.7-0.8 are acceptable and values above 0.9 are exceptionally good. In this table, the KMO measure is 0.771 which is an acceptable measure.

Bartlett's test is another indication of the strength of the relationship among variables. This tests the null hypothesis that the correlation matrix is an identity matrix. An identity matrix is one in which all the diagonal elements are 1 and all off diagonal elements are close to 0 . Therefore, this test is significant that is the significance value is less than 0.05 . The significant test tells us that the correlation matrix is not an identity matrix. Therefore, there is some relationship between the variables we hope to include in the analysis. For these data, Bartlett's test is highly significant $(\mathrm{p}<0.001)$. Therefore, factor analysis is appropriate.

\subsubsection{Communalities}

Table $1 \mathrm{KMO}$ and Bartlett's Test

\begin{tabular}{llr}
\hline Kaiser-Meyer-Olkin Measure of Sampling Adequacy. & .771 \\
\hline Bartlett's Test of Sphericity & Approx. Chi-Square & 1482.147 \\
& Df & 136 \\
& Sig. & .000 \\
\hline
\end{tabular}




\section{Communalities}

\begin{tabular}{|c|c|c|}
\hline & Initial & Extraction \\
\hline $\begin{array}{l}\text { How much do you spend on shopping through } \\
\text { online social media? }\end{array}$ & 1 & 0.829 \\
\hline $\begin{array}{l}\text { I prefer shopping on social media because the } \\
\text { price of the product is cheap. }\end{array}$ & 1 & 0.689 \\
\hline $\begin{array}{l}\text { I am influenced by discounts provided by } \\
\text { various brands on social media. }\end{array}$ & 1 & 0.802 \\
\hline $\begin{array}{l}\text { My purchase on social media is highly } \\
\text { influenced by return policy. }\end{array}$ & 1 & 0.824 \\
\hline $\begin{array}{l}\text { My purchase on social media is influenced by } \\
\text { warranty period. }\end{array}$ & 1 & 0.779 \\
\hline $\begin{array}{l}\text { I shop on social media because of the wide } \\
\text { range of products. }\end{array}$ & 1 & 0.853 \\
\hline $\begin{array}{l}\text { I am willing to rely on advertisements on social } \\
\text { media that conveyed information when } \\
\text { making a purchase-related decision. }\end{array}$ & 1 & 0.794 \\
\hline $\begin{array}{l}\text { Advertisement on social media is a convenient } \\
\text { source of product information. }\end{array}$ & 1 & 0.938 \\
\hline $\begin{array}{l}\text { Advertisements on social media are } \\
\text { entertaining. }\end{array}$ & 1 & 0.872 \\
\hline $\begin{array}{l}\text { The comments on/about the product / brand } \\
\text { on social media (Facebook, Instagram) are } \\
\text { helpful or valuable. }\end{array}$ & 1 & 0.875 \\
\hline $\begin{array}{l}\text { Several characteristics of the brand instantly } \\
\text { come to my mind when I see it on social } \\
\text { media. }\end{array}$ & 1 & 0.752 \\
\hline Brands I have seen on social media are reliable. & 1 & 0.897 \\
\hline $\begin{array}{l}\text { I feel excited when I see a product on social } \\
\text { media and I end up buying it. }\end{array}$ & 1 & 0.678 \\
\hline Shopping on social media is very easy. & 1 & 0.896 \\
\hline Shopping on social media saves a lot of time. & 1 & 0.881 \\
\hline I find shopping on social media enjoyable. & 1 & 0.74 \\
\hline $\begin{array}{l}\text { I have security concerns while making an } \\
\text { online payment. } \\
\text { Extraction Method: Principal Component Anal }\end{array}$ & 1 & 0.804 \\
\hline
\end{tabular}


The next item from the output is a table of communalities which shows how much of the variance (i.e. the communality value which should be more than 0.5 to be considered for further analysis. Else these variables are to be removed from further steps in factor analysis) in the variables has been accounted for by the extracted factors.

\subsubsection{Total Variance}

From the below table, we can see that the total variance is $81.779 \%$.The first component has variance of $22.751 \%$, the second component has a variance of $14.261 \%$, and the third component is $812.636 \%$. This means that the statement that comes under component 1 is significant.

Table 2 Total Variance Explained

\begin{tabular}{|c|c|c|c|c|c|c|c|c|c|}
\hline \multirow{2}{*}{ 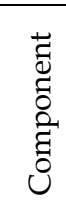 } & \multicolumn{3}{|c|}{ Initial Eigen values } & \multicolumn{3}{|c|}{$\begin{array}{l}\text { Extraction Sums of } \\
\text { Squared Loadings }\end{array}$} & \multicolumn{3}{|c|}{$\begin{array}{l}\text { Rotation Sums of } \\
\text { Squared Loadings }\end{array}$} \\
\hline & Total & $\begin{array}{c}\% \text { of } \\
\text { Varia } \\
\text { nce }\end{array}$ & $\begin{array}{c}\text { Cumu } \\
\text { lative } \\
\%\end{array}$ & Total & $\begin{array}{c}\% \text { of } \\
\text { Varia } \\
\text { nce }\end{array}$ & $\begin{array}{c}\text { Cumu } \\
\text { lative } \\
\%\end{array}$ & Total & $\begin{array}{c}\% \text { of } \\
\text { Varia } \\
\text { nce }\end{array}$ & $\begin{array}{c}\text { Cumu } \\
\text { lative } \\
\%\end{array}$ \\
\hline 1 & 5.049 & 29.702 & 29.702 & 5.049 & 29.702 & 29.702 & 3.868 & 22.751 & 22.751 \\
\hline 2 & 2.703 & 15.902 & 45.604 & 2.703 & 15.902 & 45.604 & 2.424 & 14.261 & 37.012 \\
\hline 3 & 2.246 & 13.213 & 58.817 & 2.246 & 13.213 & 58.817 & 2.148 & 12.636 & 49.648 \\
\hline 4 & 1.625 & 9.560 & 68.377 & 1.625 & 9.560 & 68.377 & 1.896 & 11.156 & 60.804 \\
\hline 5 & 1.246 & 7.331 & 75.708 & 1.246 & 7.331 & 75.708 & 1.848 & 10.868 & 71.672 \\
\hline 6 & 1.032 & 6.071 & 81.779 & 1.032 & 6.071 & 81.779 & 1.718 & 10.108 & 81.779 \\
\hline
\end{tabular}




\section{Table 3 Rotated Component Matrix4}

\begin{tabular}{|c|c|c|c|c|c|c|}
\hline & \multicolumn{6}{|c|}{ Component } \\
\hline & 1 & 2 & 3 & 4 & 5 & 6 \\
\hline $\begin{array}{l}\text { I feel excited when I see a product on } \\
\text { social media and I end up buying it. } \\
\text { I prefer shopping on social media }\end{array}$ & 0.774 & -0.051 & 0.053 & -0.146 & 0.221 & 0.058 \\
\hline $\begin{array}{l}\text { because the price of the products is } \\
\text { cheap. }\end{array}$ & 0.763 & & 0.24 & 0.161 & -0.052 & 0.138 \\
\hline $\begin{array}{l}\text { I am influenced by discounts } \\
\text { provided by various brands on } \\
\text { social media sites. }\end{array}$ & 0.722 & 0.282 & 0.434 & 0.108 & & \\
\hline $\begin{array}{l}\text { I find shopping on social media } \\
\text { enjoyable. }\end{array}$ & 0.718 & -0.042 & -0.159 & 0.392 & 0.13 & 0.164 \\
\hline $\begin{array}{l}\text { Shopping on social media saves a lot } \\
\text { of time. }\end{array}$ & 0.69 & -0.322 & -0.175 & 0.45 & -0.21 & 0.155 \\
\hline $\begin{array}{l}\text { Shopping on social media is very } \\
\text { easy. }\end{array}$ & 0.675 & -0.551 & & 0.319 & -0.174 & 0.054 \\
\hline $\begin{array}{l}\text { How much do you spend on } \\
\text { shopping through online social } \\
\text { media? }\end{array}$ & 0.586 & -0.474 & -0.068 & -0.164 & 0.478 & \\
\hline $\begin{array}{l}\text { I have security concerns while } \\
\text { making an online payment. }\end{array}$ & -0.047 & 0.857 & -0.148 & -0.208 & & \\
\hline $\begin{array}{l}\text { My purchase on social media is } \\
\text { influenced by warranty period } \\
\text { provided by various brands on } \\
\text { social media sites. }\end{array}$ & & 0.797 & -0.188 & 0.191 & 0.259 & -0.07 \\
\hline $\begin{array}{l}\text { Advertisement on social media are a } \\
\text { convenient source of product } \\
\text { information }\end{array}$ & 0.161 & -0.09 & 0.911 & & & 0.271 \\
\hline $\begin{array}{l}\text { I am willing to rely on } \\
\text { advertisements on social media that } \\
\text { conveyed information when making } \\
\text { a purchase-related decisions }\end{array}$ & & -0.286 & 0.834 & & -0.098 & -0.069 \\
\hline $\begin{array}{l}\text { The comments on about the product } \\
\text { / brand on social media(facebook, } \\
\text { instagram) are helpful or valuable. }\end{array}$ & 0.114 & & 0.057 & 0.924 & & -0.046 \\
\hline $\begin{array}{l}\text { I shop on social media because of the } \\
\text { wide range of products they offer }\end{array}$ & 0.3 & -0.185 & -0.049 & 0.625 & -0.086 & 0.573 \\
\hline $\begin{array}{l}\text { Brand I have seen on social media } \\
\text { are reliable }\end{array}$ & & 0.115 & & & 0.938 & \\
\hline $\begin{array}{l}\text { My purchase on social media is } \\
\text { highly influenced by return policy }\end{array}$ & 0.227 & 0.426 & -0.185 & 0.054 & 0.536 & -0.516 \\
\hline $\begin{array}{l}\text { Several characteristics of brand } \\
\text { instantly comes to my mind when I } \\
\text { see it on social media }\end{array}$ & 0.408 & & 0.062 & 0.081 & -0.044 & 0.757 \\
\hline $\begin{array}{l}\text { Advertisements on social media are } \\
\text { entertaining }\end{array}$ & -0.145 & 0.132 & 0.458 & -0.125 & 0.47 & 0.622 \\
\hline
\end{tabular}

Extraction Method: Principal Component Analysis.

Rotation Method: Varimax with Kaiser Normalization.

a. Rotation converged in 13 iterations. 
From the above table, we can say that the following statements are significant:

1. I feel excited when I see a product on social media and I end up buying it.

2. I prefer shopping on social media because the price of the products is cheap.

3. I am influenced by discounts provided by various brands on social media sites.

4. I find shopping on social media enjoyable.

5. Shopping on social media saves a lot of time.

6. Shopping on social media is very easy.

7. I have security concerns while making an online payment.

8. Advertisement on social media is a convenient source of product information.

9. The comments on/about the product /brand on social media (Facebook, Instagram) are helpful or valuable.

10. I shop on social media because of the wide range of products they offer.

11. Brands I have seen on social media are reliable.

12. My purchase on social media is highly influenced by the return policies.

13. Several characteristics of a brand instantly come to my mind when I see it on social media.

14. Advertisements on social media are entertaining.

The statements provided below prove Hypothesis 1 .

- I shop on social media because of the wide range of products they offer.

- I prefer shopping on social media because the price of the products is cheap.

- I am influenced by discounts provided by various brands on social media sites. 
- My purchase on social media is highly influenced by return policy.

- Majority of the respondents prefer cash on delivery as the convenient mode of payment.

Hence it can be asserted that the above mentioned statements are under component 1 . It is proven to be significant and hence proves Hypothesis 1. There is a positive and significant relationship between the services offered (price, range of products, discounts, warranty, return policy, and mode of payment), and consumer purchase intention on social networking sites.

The statements provided below prove Hypothesis 2 .

- I feel excited when I see a product on social media and I end up buying it.

- I find shopping on social media enjoyable.

- Shopping on social media saves a lot of time.

- Shopping on social media is very easy.

- I have security concerns while making an online payment.

- Advertisement on social media is a convenient source of product information.

- The comments on/about the product/brand on social media (Facebook, Instagram) are helpful or valuable.

- Several characteristics of a brand instantly come to my mind when I see it on social media.

- Advertisements on social media are entertaining.

- Brands I have seen on social media are reliable.

Hence we can say that the above mentioned statements are under component 2. It is proven to be significant and hence proves Hypothesis 2. There is a positive and significant relationship between advertisements, brands, shopping attitude, impulsive buying intentions, and consumer's purchase intentions on social networking sites. Sub variables such as warranty, brand 
awareness, brand image are less significant as they fall under component 2 and 3.

\subsubsection{Comparison Based on Demographic Variables}

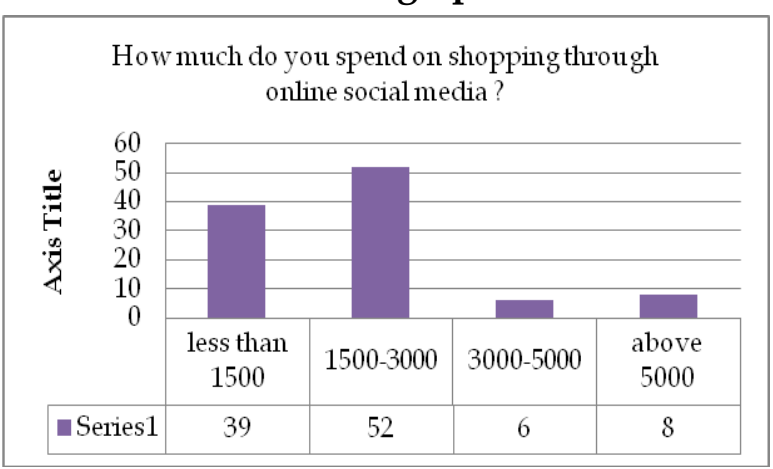

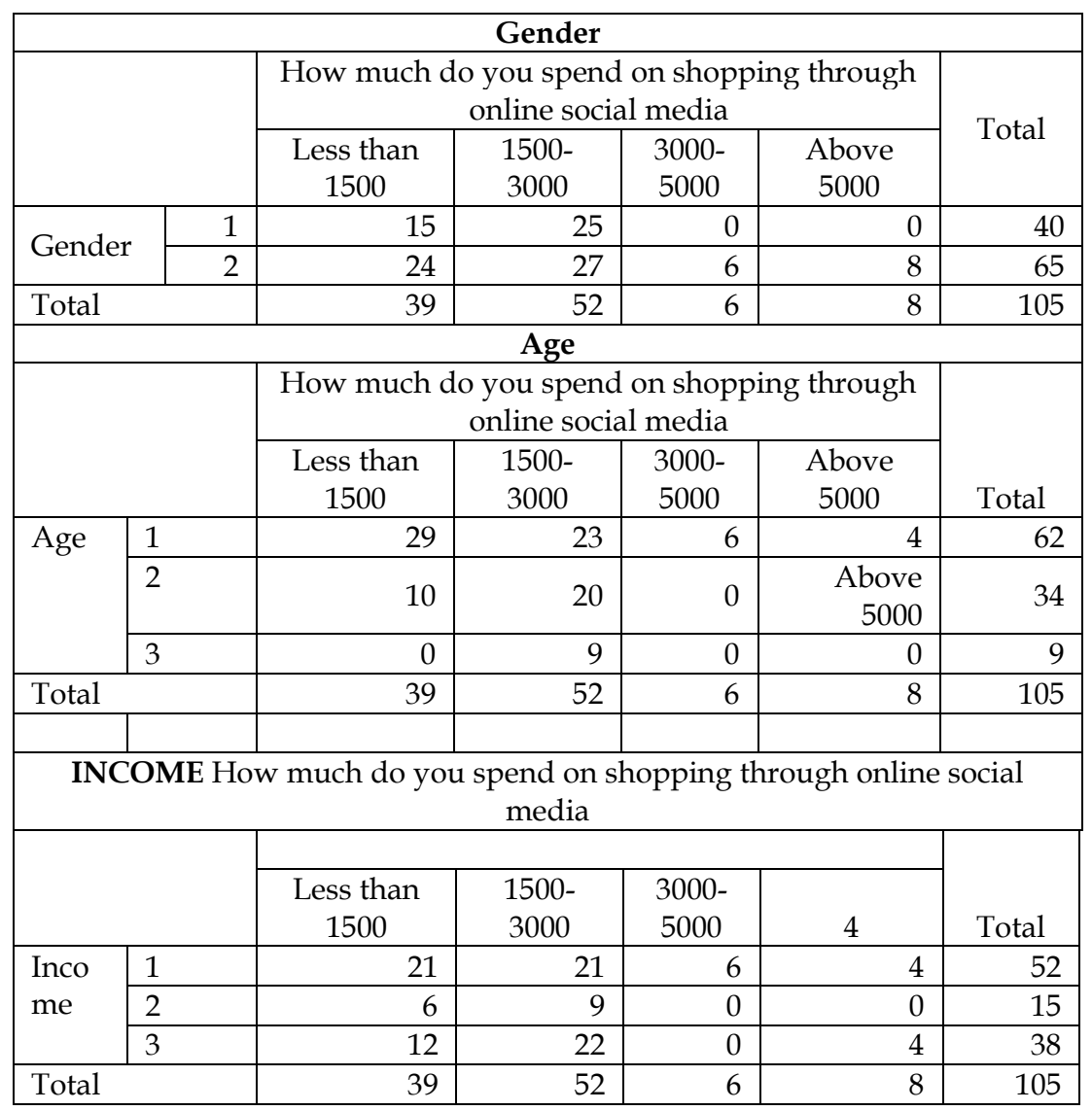


From the above data we can interpret that $49.52 \%$ of the respondents spend between $1500-3000,37.14 \%$ of the respondents spend less than 1500, $5.71 \%$ of the respondents spend between $3000-5000$, and $7.61 \%$ of the respondents spend above 5000

\section{Results}

From the above data it was interpreted that 25 of the male respondents and 27 of the female respondents spent between 15003000 . 15 of the male respondents and 24 of the female respondents spent between 1500-3000. 23 of the respondents under the age of 23, 20 of the respondents between 24-27 and 9 of the respondents between 28-35 spent between 1500-3000. 21 of the respondents who were dependent, 9 of the respondents who earned less than 20,000 and 22 of the respondents who earned between20,000-60,000 spent between 1500-3000.

25 of the male respondents and 18 of the female respondents agreed that they shop on social media because the price of the product is cheaper.

35 of the respondents who were under the age of 23, 22 of the respondents who were between 24-27 agreed that they are influenced by the discounts provided on social media. 25 of the male respondents and 51 of the female respondents agreed to the same.

35 of the respondents who were under the age of 23,22 of the respondents who were between 24-27 agreed that they are influenced by the return policy option provided by the brands on social media. 31 of the male respondents and 26 of the female respondents agreed to the same.

54 of the respondents strongly agreed that they shop through social media because of the wide range of products they have. 18 of the male respondents and 49 of the female respondents agreed to the same.

44 of the respondents under the age 23 agreed that advertisement on social media is the most convenient source of getting information of the product. 16 of the male respondents and 28 of the female respondents agreed to the same. 
44 of the respondents under the age 23 agreed that advertisements on social media are entertaining.7 of the male respondents and 18 of the female respondents agreed to the same.

40 of the respondents under the age of 23 and 19 of the respondents between the ages of 24-27 agreed that they feel excited when they see products on social media and end up buying it.9 of the male respondents and 50 of the female respondents agreed to the same.

46 of the respondents under the age of 23 agreed that social media shopping saves a lot of time. 28 of the male respondents and 43 of the female respondents agreed to the same.

58 of the respondents under the age 23,24 of the respondents between the age group 24-27 agreed that they have security concerns while making an online payment. 6 of the male respondents and 37 of the female respondents agreed to the same. $49 \%$ of the respondents who were dependent and $15 \%$ of the respondents who earned less than 20,000 agreed that discounts, wide range of products, return policies, and advertising being entertaining influenced their purchase on social media.

\section{Implication and Recommendation}

The companies should focus more on the age group of under 27. Companies should have more advertisement that is according to the interest of the users. There should be a wide range of products, discounts, and return policies should be an added service by the companies. The companies should focus not only on providing good quality products but also on low priced products. Products should have discounts, return policies as well as the 'cash on delivery' option to gain the trust of customers. The advertisements should be short but entertaining to attract customers.

\section{Conclusion}

Social networking sites act as platforms for introducing new brand, products, and for exchanging information. Social networking sites today are platforms for entrepreneurship innovations. Due to the change in the functionality of using social media platforms, the experience of consumers and social media has undergone change. 
Shopping online provides the customers a plethora of choices. Brands align their social media marketing strategies to consumer behaviour factors as identified by this study and optimise their impact.

\section{References}

Michael, P. (2017). The impact of social media on consumer buying intention. Journal of International Business Research and Marketing, 3(1), 7-13.

Kronrod, A., \& Danziger, S. (2013). Wii Will Rock You! The use and effect of figurative language in consumer reviews of hedonic and utilitarian consumption. Journal of Consumer Research, 40(4), 726-739.

Shen, B., \& Bissell, K. (2013). Social media, social me: A content analysis of beauty companies' use of Facebook, in marketing and branding. Journal of Promotion Management, 19, 629-651. DOI: 10.1080/10496491.2013.829160

Parson, A. (2013). How Does social media influence the buying behavior of consumers?, Business $\mathcal{E}$ Entrepreneurship

Chiang, K. P., \& Dholakia, R. R. (2013). Factors driving consumer intention to shop online: An empirical investigation, Journal of Consumer Psychology, 13(1), 177-183.

Krieger, K. S. A. M. (2012). Instagram retrieved from http://instagram.com/press/ [Accessed].

Darden, W. R., \& Reynolds, F. D. (2011). Shopping orientations and product usage roles. Journal of Marketing Research, 8(1), 505-508.

Han, J., \& Han, D. (2011). A framework for analysing customer value of internet business, Journal of Information Technology Theory and Application, 3(5), 25-38.

Bennett, J., Owers, M., \& Tucker, M. (2010). Workplace impact of social networking. Property Management, 28(3), 138-148

Miller, R., \& Lammas, N. (2010). Social media and its implications for viral marketing. Asia Pacific Public Relations Journal, 11, 1-9

Mitra, K., Reiss, M. C., \& Capella, L. M. (2009). An examination of perceived risk, information search and behavioural intentions in search, experience and credence services, Journal of Services Marketing, vol. 13, no. 3, pp. 208-228

Boyd, D. M., \& Ellison N. B. (2007). Social network sites: Definition, history, and scholarship. Journal of Computer-Mediated Communication, 13(1), 210-230. 
Li, C., Bernoff, J., Pflaum, C., \& Glass, S. (2007). How consumers use social networks. Retrieved on 2012-05-11 from http:// www.eranium.at/blog/upload/consumers_socialmedia.pdf Loader

Kim, Y. A., \& Srivastava, J. (2007). Impact of social influence in ecommerce decision making. Paper presented at the Proceedings of the ninth international conference on Electronic commerce.

McKnight, D., \& Chervany, N. L. (2002). What trust means in e-commerce customer relationships: an interdisciplinary conceptual typology. International Journal of Electronic Commerce, 6(2), 35-59. 